\title{
Gender, Race, and College Major: Do They Predict Modern Racism?
}

\author{
David Bryan Oxendine \\ Department of Elementary Education, School of Education, \\ University of North Carolina, USA \\ E-mail: david.oxendine@uncp.edu
}

Received: January 7, 2016 Accepted: March 1, 2016 Published: March 2, 2016

doi: 10.5296/jsss.v3i2.8835 URL: http://dx.doi.org/10.5296/jsss.v3i2.8835

\begin{abstract}
Gender and race have consistently been associated with racial prejudice and discrimination. This study investigates these relationships further along with college major. Looking at a college academic major that is overrepresented with a gender and racial group associated with modern racism to discover if this leads this academic major to predict modern racism attitudes and beliefs. The research participants consisted of 225 undergraduate and graduate students at an ethnically diverse regional university in the southeastern United States. As hypothesized, gender, race, and college major are significant predictors of modern racism.
\end{abstract}

Keywords: Gender, race, College major, Modern racism, Racial attitudes

\section{Introduction}

Recently the University of Missouri President and Chancellor under pressure by students, parents, and the community resigned because of the lack of a response by university administrators addressing issues of racism and discrimination on campus extending from the 2014 events in Ferguson. Among the protests, one student refused to eat, but only when the football team refused to play did university officials act. This gave the impression that only when large sums of money were at stake did officials take action. This is the most recent event to occur stemming from issues concerning racism and discrimination.

The better part of the past century, research has consistently revealed a strong relationship between gender, race, and prejudice and modern racism (Allport, 1954; Cowan, 2005; Helgeson, 2005; McConahay, 1983, 1986; McConahay, Hardee, \& Batts, 1981; Oxendine, 2016). Much of this research suggests that males tend to have greater levels of prejudice and negative modern racist attitudes than do females. Additionally, numerous studies suggest that race (White) is a significant factor related to prejudice and modern racism. Following this 
line of research, if males (gender) and White participants (race) are significantly related to modern racism, then it would seem to reason that an academic major that is disproportionally populated with White males, then this academic discipline might be vulnerable to modern racism as a covert value system.

Today colleges and universities have a greater diversity of students than ever before. Many schools that traditionally had been single-gender campuses are now allowing both male and females, as are Historically Black Colleges and University's opening rosters to all racial groups. Having established that gender and racial group significantly correlates with prejudice and modern racism, could this information determine if certain university disciplines or academic majors predict prejudice and modern racism attitudes and beliefs? In other words, are some university major is more susceptible to tolerating greater levels of prejudice and modern racism? A focus of the present study will examine what we know of these factors and hypothesize if certain academic majors predict greater levels of prejudice and modern racism attitudes and beliefs.

\subsection{Gender}

Within discussions of racial prejudice and discrimination, issues of gender differences often appear. Numerous studies suggest there is a significant gender difference with males appearing more likely to hold and exhibit greater instances of racial and ethnic prejudice and discrimination (Allport, 1954; Bakanic, 2009; Helgeson, 2005; Jackson, 2011; Jones, 2002; McConahay, 1983, 1986; Nelson, 2006; Ponterotto, Burkand, Rieger, Grieger, D’Onofrios, Dubusison, Heenehan, Millstein, Parisi, Rath, \& Sax, 1995). According to Oxendine and Nacoste (2007), this difference between males and females viewed through the lens of Gilligan's (1982) "ethic of care" may explain this phenomenon. The ethic of care model suggests female moral reasoning is more concerned with relationships, responsibility, and to care about other's well-being. Oxendine and Nacoste state, "females tend to have a relational bias that focuses on the consequences of decisions and actions for individual suffering and hurt" (p. 1616).

The social structure of a society tends to dictate and define behavior that is appropriate and behavior, which is not appropriate. Gender roles and stereotypes are so common in modern life that most people do not even recognize it occurring or that they are guilty of it as well. In the 21 st century when one thinks of a "nurse" almost immediately a "female nurse" comes to mind even though "male" nurses are more common today. Negative attitudes, stereotypes, and beliefs based on gender are considered sexism (Bakanic, 2009; Helgeson, 2005; Nelson, 2006; Rothenberg, 2007; 2008). Why do such negative attitudes, beliefs, and gross generalizations toward females continue? For example, in the United States, 2008 presidential campaign in the United States had the potential to have two unknown possibilities: a White female or a Black male for the presidential nomination. Apparently, the less risky unknown was to nominate a Black male as opposed to a White female (Brinkman \& Rickard, 2009; Brinkman, Garcia, \& Rickard, 2011; Garcia-Retamero \& López- Zafra, 2006; Lehman, 2012; Leppel, 2001; Nadal, Davidoff, Davis, Wong, Marshall, \& McKenzie, 2015; Stefurak, Taylor, \& Mehta, 2010). 


\subsection{Race}

Today most scholars agree that methods to categorize people "racially" based on visible physical traits are flawed (Bakanic, 2009; Jackson, 2011; Jones, 2002; Nelson, 2006). Although it is true groups of people can have similar physical traits, but is unreliable and problematic as a means of determining if people are genetically similar. There can be greater genetic variation within a group than between groups. However, according to Jackson, from a pure scientific knowledge based application these genetic variations may be useful in certain cases when related to human health since there are diseases that have a genetic origin.

This issue is more difficult to resolve because for so long people erroneously thought race had an immutable biological basis. Even today, a large percentage of the population thinks that race is biologically determined. Scholars in fields such as evolutionary biology, anthropology, social psychology and other related disciplines agree that biology as determining race fails on several levels and is meaningless (Bakanic, 2009; Jackson, 2011; Jones, 2002; Nelson, 2006). These characteristics used as indicators for racial groups are not genetically discreet, they are not reliably measured, nor are they scientifically meaningful. Many psychologists state that racism develops as early in preschool years continuing through childhood, adolescence, and young adulthood (Cokely, Tran, Hall-Clark, Chapman, Bessa, Finley, \& Martinez, 2010; Dovidio, Gaertner, Kawakami, \& Hodson, 2002; Rothenberg, 2007).

Therefore, it should be no surprise to find racial prejudice on college and university campuses throughout the United States today (Bakanic, 2009; Bryan, Wilson, Lewis, \& Willis, 2012; Gassner, \& McGuigan, 2014).

\subsection{College Major}

Recent research has established that STEM academic programs have traditionally shown discrimination and prejudice toward female students (Berryman-Fink, 2006; Brinkman \& Rickard, 2009; Brinkman, Garcia, \& Rickard, 2011; Deemer, Smith, Carroll, \& Carpenter, 2014; Garcia-Retamero \& López- Zafra, 2006; Lehman, 2012; Leppel, 2001; Levin, Van Laar, \& Sidnaius, 2003; Nadal, Davidoff, Davis, Wong, Marshall, \& McKenzie, 2015; Rice, Lopez, Richardson, \& Stinson, 2013). One such academic discipline, business, traditionally over-represents White males. Therefore, business majors as an academic discipline, according to Leppel, previously and currently supported in the literature as significantly related to modern racist attitudes and prejudice, may serve as a predictor modern racist attitudes and beliefs.

\subsection{Modern Racism}

The social psychological theory attempts to explain the evolution of "old-fashioned" racism, characterized by open and blatant bigotry with disregard of hiding such feelings into its present form, modern racism. According to McConahay $(1983,1986)$, modern racists deny that racism exists, but they may have some deep-seated racial attitudes while striving to appear non-racial. In other words, modern racism exists under the radar in subtle, covert manifestations and actions. In order to continue to behave consistent with their negative attitude and feelings toward minorities, the modern racist must find rooted in their environment a plausible explanation that justifies their "modern racist" behavior that can be 
viewed as nonprejudiced (Augoustinos \& Reynolds, 2002; Brief, Dietz, Cohen, Pugh, \& Vaslow, 2000; Cokely et al., 2010; Jackson, 2011; McConahay, 1983, 1986; McConahay et al., 1981).

This phenomenon developed to work on two levels; White's giving the appearance of non-racist attitudes and beliefs while simultaneously retaining racist attitudes and beliefs (Brief et al., 2000; McConahay, 1983, 1986; Sydell \& Nelson, 2000). This dissociation and denial of negative feelings toward minorities are defense mechanisms creating an atmosphere making it difficult to recognize and face the issue.

\subsection{The Current Study}

The current study attempts to investigate if gender, race, and college major can predict modern racism. For simplicity, this study utilizes the broader term "racial group" differentiated as White and Non-White. The study participants were drawn from a university in the southeastern United States with the following demographics: gender (male $=38 \%$, female $=62 \%$ ), race/ethnicity (American Indian $=15 \%$, Asian $=2 \%$, Black $=35 \%$, Hispanic $=5 \%$, International $=1 \%$, White $=38 \%$, Other $=4 \%)$. The total enrollment was 6,441 (Office of Institutional Research, University of North Carolina at Pembroke, 2015).

\subsubsection{Hypotheses}

Hypothesis 1 states that gender (male) is a significant predictor of modern racism. Hypothesis 2 states that race (White) is a significant predictor of modern racism. Hypothesis 3 states that college major (School of Business) is a significant predictor of modern racism. Hypothesis 4 states that gender, race, and college major predict modern racism.

\section{Method}

\subsection{Participants}

Participants selected for this study were 225 undergraduate and graduate college students (females $152=67.6 \%$ and males $73=32.4 \%$ ) enrolled at a small southeastern university. The age range for the participants was as follows: $18-20=(\mathrm{n}=54) 24 \%, 21-23=(\mathrm{n}=87) 38.7 \%$, $24-26=(\mathrm{n}=23) 10.2 \%, 27-29=(\mathrm{n}=15)(6.7 \%)$, and $30+=(\mathrm{n}=46) 20.4 \%$.

\subsection{Demographics}

Participants responded to a series of questions that indicated the degree of a variety of demographic items such as religious orientation and affiliation, political orientation, socioeconomic status, ethnicity, sex, age, college classification, and college major. The university used in this study has the distinction as the second most diverse university campus in terms of ethnic diversity in the southeastern United States (America's Best Colleges, 2014).

\subsection{Racial Group Membership}

Participants self-reported their ethnicity as follows: American Indian $(\mathrm{n}=49) 21.8 \%$, Black $(\mathrm{n}=39) 17.3 \%$, Asian $(\mathrm{n}=5) 2.2 \%$, Hispanic $(\mathrm{n}=7) 3.1 \%$, White $(\mathrm{n}=117) 52 \%$, and those identified as Other $(\mathrm{n}=8) 3.6 \%$. This sample is representative of the university population. (White $=117$, Non-White $=108$ ). 


\subsection{Measures}

\subsubsection{Modern Racism Scale (MRS)}

McConahay's (1986) Modern Racism Scale is a 7-item instrument designed to assess participants' level of racism attitudes and beliefs. The MRS was designed to be nonreactive and is rated on a 5-point Likert-type scale with $1=$ Strongly Disagree to $5=$ Strongly Agree, on which higher scores indicate racial attitudes and beliefs. Reliability analysis using Cronbach's alpha for the current study yielded a coefficient of .82 $(\mathrm{M}=2.217, \mathrm{SD}=0.890)$ consistent with McConahay's findings (Oxendine, 2016). See Table 1.

Table 1. Modern racism scale

1. Over the past few years, the government and news media have shown more respect to Blacks than they deserve

2. It is easy to understand the anger of Black people in America

3. Discrimination against Blacks is no longer a problem in the United States

4. Over the past few years, Blacks have gotten more economically than they deserve

5. Blacks have more influence upon school desegregation plans than they ought to have

6. Blacks are getting too demanding in their push for equal rights

7. Blacks should not push themselves where they are not wanted

Note. *Item scored for Racism Denial subscale. $\mathrm{N}=225$. Items scored on the following response choices $(1=$ Strongly Disagree $-5=$ Strongly Agree). Modern Racism Scale (MRS).

\subsection{Procedures}

At the beginning of the semester students in the School of Education, School of Business, a psychology course, and a general education political science introductory class received an informed consent form and questionnaire packet. Respondents voluntarily completed the questionnaires without incentives. Five participants failed to complete the surveys and their data was not included. Debriefing of all participants concerning the nature of the study occurred followed after completion of the surveys.

\section{Results}

\subsection{Theoretical Predictions}

Correlations among the study variables indicated gender, race, and college major revealed significant relationships with modern racism. College major was significantly related to modern racial attitudes and beliefs, but lower in magnitude. Additionally, racial group was inversely significantly to modern racial attitudes and beliefs. See Table 2 for zero-order correlations between the study variables. 
Table 2. Zero-Order correlations between study variables

\begin{tabular}{lllll}
\hline & $G$ & $R G$ & $C M$ & $M R$ \\
\hline 1. Gender & 1 & & & \\
2. Racial Group & -.096 & 1 & & \\
3. College Major & $.221^{*}$ & .056 & 1 & \\
4. Modern Racism & $.255^{*}$ & $-.139^{*}$ & $.225^{*}$ & 1 \\
\hline
\end{tabular}

Note. * Correlation is significant at the $\mathrm{p}<.05$ level (2-tailed). $\mathrm{n}=225$. ** Correlation is significant at the $\mathrm{p}<.01$ level (2-tailed). $\mathrm{n}=225$. Modern Racism Scale (MRS).

An important question of this study is to determine the predictive power of gender, racial group, and college major, therefore, a hierarchical multiple regression analysis was performed. To test if modern racism is predicted by gender, racial group, and college major a multiple regression analysis using the enter method was performed. A significant model emerged $F(3,221)=6.202, p<.0001$. Tests for multicollinearity indicated that a high level of tolerance $=.940, .985$, and .945 for gender, racial group, and college major, respectively. Gender was the first variable entered followed by racial group and college major. Beta coefficients for the three variables for the three predictors were gender $\beta=.187, t=2.806, p$ $<.005 \mathrm{~s}$; racial group $\beta=-.127, \mathrm{t}=-1.957, \mathrm{p}<.052 \mathrm{~ns}$; college major $\beta=.118, \mathrm{t}=1.772, \mathrm{p}$ $<.078$ ns. See Table 3.

Table 3. Hierarchical multiple regression analysis gender, racial group, \& college major predicting modern racism

\begin{tabular}{llcccclcl}
\hline Variable & $R$ & $R^{2}$ & $R_{a d j}^{2}$ & $\Delta R^{2}$ & $F_{c h g}$ & $P$ & $d f_{1}$ & $d f_{2}$ \\
\hline Modern Racism & $.279 *$ & .078 & .065 & .078 & 6.202 & $<.0001 * *$ & 3 & 221 \\
\hline
\end{tabular}

Note. $* \mathrm{p}<.05, * * \mathrm{p}<.01$.

Hypothesis 1 and 2 states that gender (male) and racial group (White), respectively will be significant predictors of modern racism. An examination of the means revealed that males $(\mathrm{M}$ $=2.452, \mathrm{SD}=.613)$ significantly predicted modern racism as compared to females $(\mathrm{M}=$ $2.166, \mathrm{SD}=.565)$ therefore, supporting hypothesis 1 . An explanation of the means revealed that White participants $(\mathrm{M}=2.338, \mathrm{SD}=.586)$ significantly predicted modern racism as compared to Non-White participants $(\mathrm{M}=2.173, \mathrm{SD}=.596)$ therefore, supporting hypothesis 2.

Hypothesis 3 states that college major (School of Business) predicts modern racism. A stepwise multiple regression analysis excluded racial group and college major revealing beta coefficients for gender $\beta=.286, \mathrm{t}=3.451, \mathrm{p}<.001 \mathrm{~s}$. Beta coefficients for racial group and college major as the predictor revealed $\beta=-.118, \mathrm{t}=-1.813, \mathrm{p}<.07 \mathrm{~ns}$ and $\beta=.107, \mathrm{t}=.1 .610$, $\mathrm{p}<.109 \mathrm{~ns}$, respectively. See Table 4 . 
Table 4. Stepwise multiple regression analysis gender, racial group, and college major predicting modern racism

\begin{tabular}{llcccclcl}
\hline Variable & $R$ & $R^{2}$ & $R_{\text {adj }}^{2}$ & $\Delta R^{2}$ & $F_{\text {chg }}$ & $P$ & $d f_{1}$ & $d f_{2}$ \\
\hline Modern Racism & $.225^{*}$ & .051 & .046 & .051 & 11.911 & $<.001 * *$ & 1 & 222 \\
\hline
\end{tabular}

Note. $* \mathrm{p}<.05, * * \mathrm{p}<.01$. Excluded racial group and college major.

However, using the enter method only with college major a significant model emerged: $\mathrm{F}(1$, $223)=5.261, \mathrm{p}<.023$. A follow-up one-way ANOVA revealed a significant relationship between college major and modern racism. This analysis revealed a significant result $\mathrm{F}(3$, $221)=3.922, \mathrm{p}<.009, \mathrm{pp} 2=.05$, which is a medium effect according to Cohen (1988). The observed power of the effect was .82 ; therefore, if a sample drawn from the population with an effect size equal to the effect size of this sample, there is an $80 \%$ chance of obtaining a significant result. As stated hypothesis 3 found partial support. See Table 5.

Table 5. Multiple regression analysis college major predicting modern racism

\begin{tabular}{lcccccccc}
\hline Variable & $R$ & $R^{2}$ & $R_{a d j}^{2}$ & $\Delta R^{2}$ & $F_{c h g}$ & $P$ & $d f_{1}$ & $d f_{2}$ \\
\hline College Major & $.152 *$ & .023 & .019 & .023 & 5.261 & $<.023 *$ & 1 & 223 \\
\hline
\end{tabular}

Note. $* \mathrm{p}<.05, * * \mathrm{p}<.01$.

Hypothesis 4 states that gender, race, and college major predict modern racism. Using the enter method, a significant model emerged. These results found support for hypothesis 4 . See Table 2 .

\section{Discussion}

The purpose of this study was to examine whether gender, race, and college major are useful predictors of prejudicial and modern racial attitudes and beliefs. Discrimination based on gender stems from outdated gender-role stereotyping and prejudices (Helgeson, 2005). According to social identity theory (Tajfel \& Turner, 1979; 1986), being a member of a racial group creates within individuals a sense of belonging, which in turn promotes a positive self-concept. According to McConahay $(1983,1986)$, modern racists deny that racism exists, but they may have some deep-seated racial attitudes while striving to appear non-racial. In other words, modern racism exists under the radar in subtle, covert manifestations and actions. Finally, this study examined academic college major, to determine if academic majors, which stereotypically tends to over-represent White males and under-represent other minority groups would be useful as a predictor modern racist attitudes and beliefs.

Hypothesis 1 states that gender (male) would predict modern racial attitudes. The results suggest that racial group does not add to the predictability of modern racial attitudes, but gender was a significant predictor. This is consistent with previous studies that suggest that females are more sensitive to social injustices than are their male counterparts (Neville et al., 2000; Neville, Spanierman, \& Doan, 2006). As predicted, males responded with greater levels of prejudicial and racial attitudes than did females. A careful examination of the means 
suggests that males $(\mathrm{M}=2.451, \mathrm{SD}=.613)$ had higher modern racial attitudes than did females $(\mathrm{M}=2.166, \mathrm{SD}=.565)$. According to social dominance orientation theory (SDO), defined as the desire that one's in-group dominate and be superior to out-groups, this manifestation appears to be quite strong in male subjects (Akrami \& Ekehammar, 2006; Snellman \& Ekehammar, 2005).

Hypothesis 2 states race (White) predicts modern racism. Consistent with the literature, hypothesis 2 found support with White group participants demonstrating greater levels of modern racial attitudes and beliefs when compared to Non-White group participants, therefore, racial group was a significant predictor of modern racism.

Hypothesis 3 states that college major predicts modern racism. Further examination of the means revealed School of Business $(\mathrm{M}=2.621, \mathrm{SD}=.749)$ with significantly greater levels of modern racist attitudes and beliefs as compared to Arts and Sciences ( $\mathrm{M}=2.293$, SD $=.588)$, and School of Education $(\mathrm{M}=2.189, \mathrm{SD}=.564)$. This would suggest that academic disciplines that consist largely of demographics that separately exhibit greater levels of modern racism might carry over to the discipline in general. Therefore, if considering only college major hypothesis 3 found support.

Hypothesis 4 states that gender, race, and college major predict modern racial attitudes and beliefs. A hierarchical multiple regression analysis revealed the variables taken together are significant predictors of modern racism. The strong effect of gender enhances the somewhat weaker effect of college major. As stated earlier college major alone is a significant predictor of modern racist attitudes and beliefs. The data above give support to hypothesis 4 .

\subsection{Theoretical and Applied Implications}

Do gender, race, and college major predict prejudicial and modern racial attitudes and beliefs? From a theoretical perspective, the minimal significance of racial group in this particular sample may derive from the above average diversity represented in this study, specifically by a large number Lumbee American Indian population. The current variance between these samples may be the result of previous studies was composed primarily of White and Black samples. The Lumbee of North Carolina is the largest tribe east of the Mississippi and the ninth largest in the United States (Dial, 1993, Dial \& Eliades, 1996; Sider, 1993, 2003). The university campus from which this sample was drawn may be unique as well. This university was founded as an American Indian Normal School in 1887 to teach American Indians to become teachers, from the 1940s until 1953 was the only state, supported four-year American Indian serving college in the United States (Dial, 1993; Dial \& Eliades, 1996; Sider, 1993, 2003).

Social dominance orientation theory (SDO) is a possible explanation for the gender effect that males and White participants exhibit greater modern racial attitudes than females and Non-White participants (Akrami \& Ekehammar, 2006; Snellman \& Ekehammar, 2005). Individuals high in SDO would discriminate against females even within the same racial or ethnic group. Social dominance focuses on people's desire to maintain the dominance of their in-group (in this case males), so their opposition may be motivated to maintain the distribution of benefits that are currently held by the dominant demographic in society, such as wealth, education, and employment (Whitley, 1999; Whitley \& Kite, 2006). Conversely, 
according to Gilligan (1982), females may tend to be more sensitive to social inequities. Future research should investigate whether SDO is a major contributing factor that demonstrates that males hold more prejudicial and modern racial attitudes.

The sociohistorical context of the sample of this study plays an important role as well. The sample in this particular study is from a university community that has a long history of tri-racial (Lumbee American Indian, Black, and White) intergroup contact. These environmental factors have created intergroup tensions, which at times has intersected both the community and the university (Sider, 1993, 2003). Future research should replicate this study with a similar university population to determine exactly how influential the diverse ethnic environmental context of the present study had on the results.

\subsection{Limitations and Future Research}

Previous studies primarily employed White and Black samples designed to measure modern racist attitudes and beliefs from White participants (Neville, Lilly, et al, 2000; Neville, Spanierman, et al., 2006). This study attempted to access modern racial attitudes from a large sample of American Indian participants in addition to White and Black participants. Future research should investigate methods to adapt these measures to tap the various experiences of diverse populations. There could be slight differences because of employing a broad interpretation of groups as White and Non-White as stated earlier. Previous research suggests that most people because of advantage as opposed to disadvantage view prejudice, racism, and discrimination as White and Black issues even with a clear understanding there are differences within and between racial and or ethnic groups (Bakanic, 2009; Bryan et al., 2012; Dryer, 2008; Gallagher, 2011).

One might question the generalizability external validity of this study with the use of students with issues of prejudice and modern racial attitudes and beliefs. Based on the existing results, it would appear that college student populations might mirror the greater population with differences only in magnitude. Prejudicial and racial beliefs are learned behaviors (Whitley, 1999; Whitley \& Kite, 2006) and since most university populations enter this environment from their various locations across the United States and other nations, appear to tap into these diverse behaviors. Future research should investigate diverse populations to determine which relationships and how other mediating factors may influence an older, more mature population.

\section{Conclusion}

The present study explores the question if gender, racial group, and college major are significant predictors of modern racism attitudes and beliefs. The results of this study support previous research findings of significant relationships between gender, race, and modern racism. Additionally, gender, race, and college major confirmed the hypotheses as significant predictors of modern racism, although, the latter provided weaker predictive power, nonetheless, still a significant factor. The reader should note that these findings in no way indicate an inherent harsh racist intent to business major or the business world, but only that there exists bias that lends itself to possible prejudice and discrimination that should be pointed out. A logical explanation for this could be the drawing a sample population of a more diverse sample compared to previous studies relying primarily on a Black and White 
population. The inclusion of a large third traditionally disadvantaged group, Lumbee American Indians may explain differences in the present results (Oxendine \& Nacoste, 2007; Sider, 1993, 2003).

\section{References}

Akrami, A., \& Ekehammar, B. (2006). Right-wing authoritarianism and social dominance orientation. Their roots in big-five personality factors and facets. Journal of Individual Differences, 27(3), 117-126. http://dx.doi.org/10.1027/1614-0001.27.3.117

Allport, G. W. (1954). The nature of prejudice. Reading, MA: Addison-Wesley.

America's Best Colleges. (2014). U. S. News and World Report. Washington D. C.

Augoustinos, M., \& Reynolds, K. J. (2002). Prejudice, racism, and social psychology. In M. Augoustino, \& K. J. Reynolds (Eds.), Understanding Prejudice, and Social Conflict (pp. 1-23). London: Sage Publications.

Bakanic, V. (2009). Prejudice: Attitudes about race, class, and gender. New Jersey: Pearson.

Berryman-Fink, C. (2006). Reducing prejudice on campus: The role of intergroup contact in diversity education. College Student Journal, 40(3), 511-516. http://dx.doi.org/10.1080/14675980600841751

Brief, A. P., Dietz, J., Cohen, R. R., Pugh, S. D., \& Vaslow, J. B. (2000). Just doing business: Modern racism and obedience to authority as explanations. Organizational behavior and Human, 81(1), 72-97. http://dx.doi.org/10.1006/obhd.1999.2867

Brinkman, B. G., Garcia, K., \& Rickard, K. M. (2009). College students' description of everyday gender prejudice. Sex Roles, 61, 461-475. http://dx.doi.org/10.1007/s11199-009-9643-3

Brinkman, B. G., Garcia, K., \& Rickard, K. M. (2011). "What I wanted to do was..." Discrepancies between college women's desired and reported responses to gender prejudice. Sex Roles, 65, 344-355. http://dx.doi.org/10.1007/s11199-011-0020-7

Bryan, M. L., Lewis, B. S., Lewis, A. A., \& Willis, L. E. (2012). Exploring the impact of "race talk" in the education classroom: Doctoral student reflections. Journal of Diversity in Higher Education, 5(3), 123-137. http://dx.doi.org/10.1037/a0029489

Cohen, J. (1988). Statistical power analysis for the behavioral sciences (2nd ed.). New Jersey: Lawrence Erlbaum Publishers.

Cokely, K. O., Tran, K., Hall-Clark, B., Chapman, C., Bessa, L., Finley, A., \& Martinez, M. (2010). Predicting student attitudes about racial diversity and gender equity. Journal of Diversity in Higher Education, 3(3), 187-199. http://dx.doi.org/10.1037/a0020467

Cowan, G. (2005). Interactions at racially diverse university campuses. The Journal of Social Psychology, 145(1), 49-63. http://dx.doi.org/10.3200/socp.145.1.49-64

Deemer, E. D., Smith, J. L., Carroll, A. N., \& Carpenter, J. P. (2014). Academic procrastination in STEM: Interactive effects of stereotype threat and achievement goals. The Career Development Quarterly, 62, 143-155. http://dx.doi.org/10.1002/j.2161-0045.2014.00076.x

Dial, A. L. (1993). The Lumbee. Indians of North America series. New York: Chelsea House. 


\section{MInstitute Macrothink $_{\text {Ins }}$}

Journal of Social Science Studies

ISSN 2329-9150

2016, Vol. 3, No. 2

Dial, A. L., \& Eliades, D. K. (1996). The Only Land I Know: A History of the Lumbee Indians. San Francisco, CA: Indian Historian Press.

Dovidio, J. F., \& Gaertner, S. L. (1986). Prejudice, discrimination, and racism: Historical trends and contemporary approaches. In J. F. Dovidio, \& S. L. Gaertner (Eds.), Prejudice, Discrimination, and Racism (pp. 1-34). New York: Academic Press.

Dyer, R. (2008). The matter of Whiteness. In P. S. Rothenberg White privilege: Essential readings on the other side of racism (3rd ed.) (pp. 9-14). New York: Worth Publishers.

Gallagher, C. A. (2011). Rethinking the color line: Readings in race and ethnicity (5th ed.), New York: McGraw-Hill.

Garcia-Retamero, R., \& López-Zafra, E. (2006). Prejudice against women in male-congenial envirnoments: Perceptions of gender role congruity in leadership. Sex Role, 55, 51-61. http://dx.doi.org/10.1007/s11199-006-9068-1

Gassner, B., \& McGuigan, W. (2014). Racial prejudice in college students: A cross-sectional examination. College Student Journal, 48(2), 249-256.

Gilligan, C. (1982). In a different voice: Psychological theory and woman's development. Cambridge, MA: Harvard University Press.

Helgeson, V. S. (2005). Psychology of gender (2nd ed.). New Jersey: Pearson.

Jackson, L. M. (2011). The psychology of prejudice: From attitudes to social action. Washington, D. $\quad$ C.: American Psychological Association. http://dx.doi.org/10.1037/12317-000

Lehman, B. (2012). The impacts of friendship groups' racial composition when perceptions of prejudice threaten students' academic self-concept. Social Psychology Education, 15, 411-425. http://dx.doi.org/10.1007/s11218-012-9190-6

Leppel, K. (2001). Race, Hispanic ethnicity, and the future of the college business major in the United States. Journal of Education for Business, 76(4), 209-215. http://dx.doi.org/10.1080/08832320109601312

Levin, S., Van Laar, C., \& Sidanius, J. (2003). The effects of ingroup and outgroup friendships on ethnic attitudes in college: A longitudinal study. Group Processes \& Intergroup Relations, 6(1), 76-92. http://dx.doi.org/10.1177/1368430203006001013

McConahay, J. B. (1983). Modern racism and modern discrimination: The effects of race, racial attkitudes, and context on simulated hiring decisions. Personality and Social Psychology Bullettin, 9, 551-558. http://dx.doi.org/10.1177/0146167283094004

McConahay, J. B. (1986). Modern racism, ambivalence, and the Modern Racism Scale. In J. F. Dovidio, \& S. L. Gaertner (Eds.), Prejudice, discrimination, and racism (pp. 61-89). Orlando, FL.: Academic Press.

McConahay, J. B., Hardee, B. B., \& Batts, V. (1981). Has racism declined? It depends upon who's asking and what is asked. Journal of Conflict Resolution, 25, 563-579. http://dx.doi.org/10.1037/t03873-000

Nadal, K. L., Davidoff, K. C., David, L. S., Wong, Y., Marshall, D., \& McKenzie, V. (2015). A qualitative approach to intersectional micoaggressions: Understanding influences of race, 
ethnicity, gender, sexuality, and religion. Qualitative Psychology, 2(2), 147-163. http://dx.doi.org/10.1037/qup0000026

Neville, H. A., Lilly, R. L., Duran, G., Lee, R. M., \& Browne, L. (2000). Construction and initial validation of the Color-Blind Racial Attitudes Scale (CoBRAS). Journal of Counseling Psychology, 47(1), 59-70. http://dx.doi.org/10.1037//0022-0167.47.1.59

Nelson T. D. (2006). The psychology of prejudice (2nd ed.). New York: Pearson.

Neville, H. A., Spanierman, L., \& Doan, B. T. (2006). Exploring the association between color-blind racial ideology and multicultural counseling competencies. Cultural Diversity and Ethnic Minority Psychology, 12(2), 275-290. http://dx.doi.org/10.1037/1099-9809.12.2.275

Office of Institutional Research. (2015). Enrollment by demographics. University of North Carolina at Pembroke retrieved from http://www.uncp.edu/sites/default/files/Images_Docs/Departments/Institutional_Effectiveness /Factbooks/New_2014/Student\%20Demographics\%20Fall\%202015.pdf

Oxendine, D. (1995). Racial identity development among Lumbee American Indian college students on a predominately White campus. Unpublished master's thesis, North Carolina State University, Raleigh.

Oxendine, D. B. (2004). The effects of social exclusion threat and justifications on perceived fairness of an ethnic validation procedure: Implications for Lumbee Federal Recognition. (Doctoral dissertation, North Carolina State University, 2004). Dissertation Abstracts International, (UMI No. 3154343).

Oxendine, D. B. (2016). The relationship between political orientation and race on modern racism. Journal of Social Science Studies, $3(1), \quad 67-82$. http://dx.doi.org/10.5296/jsss.v3i1.7933, doi.10.5296/jsss.v3i1.7933

Oxendine, D. B., \& Nacoste, R. W. (2007). Who would claim to be that, who was not? Evaluations of an ethnic validation procedure. Journal of Applied Social Psychology, 37(7), 1594-1629. http://dx.doi.org/10.1111/j.1559-1816.2007.00229.x

Ponterotto, J. G., Burkand, A., Rieger, B. P., Grieger, I., D’Onofrios, A., Dubusison, A., ... Sax, G. (1995, December). Development and initial validation of the Quick Discrimination Index (QDI). Educational and Psychological Measurement, 55(6), 1016-1031. http://dx.doi.org/10.1177/0013164495055006011

Rice, K. G., Lopez, F. G., Richardson, C. M. E., \& Stinson, J. M. (2013). Perfectionism moderates stereotype threat effects on STEM major's academic performance. Journal of Counseling Psychology, 60(2), 287-293. http://dx.doi.org/10.1037/a0032052

Sider, G. M. (1993). Lumbee Indian Histories: Race, Ethnicity, and Indian Identity in the Southern United States. New York: Cambridge University Press.

Sider, G. M. (2003). Living Indian Histories: Lumbee and Tuscarora People in North Carolina. Chapel Hill: University of North Carolina Press.

Stefurak, T., Taylor, C., \& Mehta, S. (2010). Gender-specific models of homosexual prejudice: Religiosity, authoritarianism, and gender roles, 2(4), 247-261. 


\section{Macrothink}

Journal of Social Science Studies

ISSN 2329-9150

2016, Vol. 3, No. 2

Sydell, E. J., \& Nelson, E. S. (2000). Modern racism on campus: A survey of attitudes and perceptions. The Social Science Journal, 37(4), 627-635. http://dx.doi.org/10.1016/S0362-3319(00)00105-1

Tajfel, H., \& Turner, J. C. (1979). An integrative theory of intergroup relations. In W. G. Austin, \& S. Worchel (Eds.), The Social Psychology of Intergroup Relations (pp. 33-47). Montrerey, CA: Brooks/Cole.

Tajfel, H., \& Turner, J. C. (1986). The social identity theory of intergroup behavior. In S. Worchel, \& W. G. Austin (Eds), Psychology of Intergroup Relations (2nd ed., pp. 7-24). Chicago: Nelson-Hall.

Whitley, B. E., Jr. (1999). Right-wing authoritarianism, social dominance orientation, and prejudice. Journal of Personality and Social Psychology, 77(1), 126-134. http://dx.doi.org/10.1037//0022-3514.77.1.126

Whitley, B. E., Jr., \& Kite, M. E. (2006). The psychology of prejudice and discrimination. CA: Thomson Wadsworth

\section{Copyright Disclaimer}

Copyright for this article is retained by the author(s), with first publication rights granted to the journal.

This is an open-access article distributed under the terms and conditions of the Creative Commons Attribution license (http://creativecommons.org/licenses/by/3.0/). 